\title{
Impact Analysis of Information Library Construction with Diversified access to information
}

\author{
Na Lin'1, a \\ ${ }^{1}$ Jilin Agricultural University, Changchun, Jilin Province, China \\ a36670921@qq.com
}

Keywords: Information, Pluralism, Library, Influence

\begin{abstract}
Access to information pluralism has changed the traditional concept of library collections connotation and denotation, a profound impact on library information resources construction and organization model, user behavior change information and get in the way of the first on the macro level configuration of Library Information Resources and the organization has brought a huge impact. In this paper, information pluralism on the libraries is in-depth discussed.
\end{abstract}

\section{Introduction}

With the development of Internet and information technology, resource acquisition and the introduction of the library has been expanding the scope of its concerns, the proportion of digital library resources has been improved, new resource types are also more and more attention by the library, the Library towards the diversified development of the new direction [1].

First, with computer technology, communication technology, the rapid development of multimedia technology, image, voice, and video and other non-text multimedia resources are increasingly rich, scholarly multimedia resources are more and more users of all ages and put to use, collection and preservation of multimedia resources has become an initiative to build a diversified library collection. In this regard, the Cambridge University Library in 2010--2013 Strategic Framework stated that non-text resources for collection development is very important to take advantage of a variety of channels for the collection and preservation of such resources; In addition, Cornell University Library, the British Library and Wadsworth public Library in their strategic planning has also developed visual resources and multimedia resources development objectives [1].

Secondly, due to the continuous development of network technology and rich with the site information gathering web resources the library has been gradually attention. Library began to collect and integrate a large number of web resources, and build a unified platform to reveal and retrieval.

\section{Access to information pluralism on Library Construction}

Access to information pluralism has changed the traditional concept of library collections connotation and denotation, a profound impact on library information resources construction and organization model, user behavior change information and get in the way of the first on the macro level configuration of Library Information Resources and the organization has brought a huge impact.

Organization and integration of information resources within the library request. An information retrieval purposes is one of the main ways the user access to information. The network environment, with a dramatic increase in library information resources, there has been more and more heterogeneous, heterogeneous digital resources system, resulting in the separation of library information resources and retrieval methods, which gives the user access to information resources with to a lot of inconvenience. In effect, access to information from a user perspective, the need for multiple heterogeneous libraries, heterogeneous digital resources integrated with the reorganization; library users need to get the experience from the perspective of view of library users as the core of the information resources multifaceted, multi-level integration, restructuring, integration, the establishment of resource system has a relevance to eliminate the digital information "islands", which not only improve the utilization of digital library resources, but also can be Digital resources placed on a unified platform, unified search, retrieval of information resources so convenient and easy to use 
[2]. Therefore, the use of multiple search engines participate in online information retrieval is one of the impact of new network environment of the library.

Organization and integration of information resources between libraries request. Library internal information resources to achieve integration and re-organization is only a small range of organizational form, affected by the new network environment, a few or more related Library Consortium (region) formed between the library needs to be cross-domain information integration and organization of resources, which is a broader form of organization, is the information resources of the region or the organization of the system libraries and configuration. Information Resource Organization between macro-level library is more on restructuring the allocation of resources, build a Web-based environment comprehensive literature information service platform, various types of distributed regarded each library literature information resource by a certain management and application purpose organized [3], in addition to the purpose of sharing information resources, facilitate the user to obtain information resources is also a major factor.

Request for library information resources and Internet information resources integration and organization. "Some library resources are very good, but the user may not know, or poorly understood, Google can put their collections more easily presented to the reader." [4] under the current new network environment, library, digital library, information Internet service providers and other process-oriented integration and restructuring must be faced with information resources. The Internet is an important information storage and communication carriers, but also access to information is very important channels to the full realization of the social communication and shared knowledge of information for the purpose. In the global information technology and Internet business environment, social network of libraries will eventually be connected to the Internet or other networks, one of the most significant impacts is with publishers, Internet content providers, competition between the network service providers [3].

\section{New Requirements diversified access to information submitted to the Library Construction}

Access to resources and services is the basis of content. In the library strategic planning, resources and access to services is the foundation to reveal the contents of the library service strategies. Throughout the strategic text sample institutions are focused on developing a number of library resource discovery tools to optimize access and access to resources. For example, Columbia University Library plans to reveal resources to the search engine, find tools (such as Google, Yahoo, Wikipedia) and social networking environment (such as Flickr, iTunesU, YouTube), the disclosure includes bibliographic records, archives to find assistants, image and other appropriate data, in order to fully improve the search, discovery and delivery of resources and recommend appropriate services and social labels, to improve information discovery capability [3]; Library of Congress plans to research networks through access to resources such as search and discovery systems develop measures to improve access to collections, the British Library newspaper plans to change the access mode of information and consultation with publishers outside the museum offers a variety of modes of access to authorized resources [5]; Newcastle University Library plans to develop and utilize the resource discovery tool to promote the visibility of collections [4].

Emphasize research support services. Research support has been emphasized library services. Library main strategy for this area is rich in research infrastructure over the collection, provide in-depth research and support services for specific groups. In the 35 strategic planning, research and library services in support of innovation after another, such as the British Library stressed in the plan to provide information to people willing to engage in research and provide research support services to the research community in key areas, and to influence, competitiveness, financing and ability to cooperate, public service capacity as a measure of the key research in the field of standards [2]; Library at Columbia University plans to develop and market a full range of CDRS (Control and Data Retrieval System, control and Data retrieval System) research support services, including hosting journals and conference management services, seminars and individual research and consulting, citation management tools, media access and operation support, research memo management and subject-specific data collection, access and management services [4]. 
Planning mobile services. Strategic planning sample bodies, mobile services and data collection service is a highlight innovative library services. For mobile services, the library main planning how to carry out services in the mobile technology environment, the use of mobile devices more efficient access to library collections and access to its services. For example, the British Library in the plan put forward, the use of mobile devices to complete delivery of resources and services to support the mobile office, the use of mobile devices to provide users with a directory search and important digital repository of online access services, and through normal channels (such as the use system vendors software upgrade program) and other third-party channels to jointly promote the implementation of the program [5]; In addition, Columbia University's strategic planning in their respective libraries, Leeds University Library, University College London in the proposed libraries the use of smart phones, e-book reader, iPad and handheld mobile devices to provide services and content, to promote e-services movement.

Construction of spatial information sharing service. With the change of awareness of library services, "space" has become a starting point for sharing library services (Fig.1) [6]. Many libraries in strategic planning entities are planning to transform the old space planning and design a series of user-friendly communication, discussion of "user participation in space." In this regard, the Columbia University Library will discuss plans to build a group study area, individual and collaborative research areas and group teaching area, and improve the working area of regional studies and social sciences library staff.

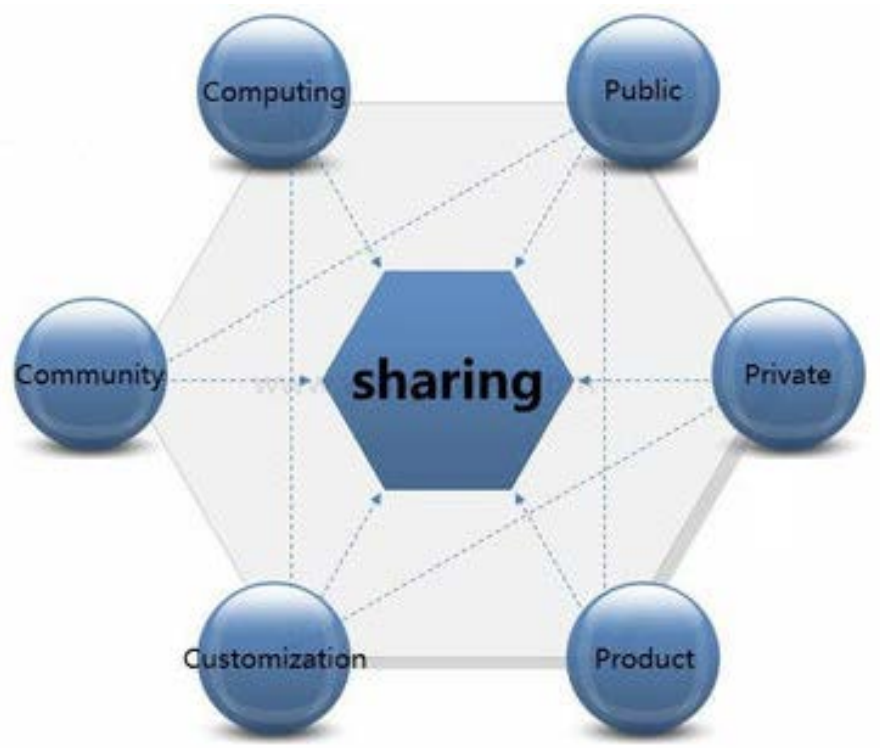

Fig.1 Construction of spatial information sharing service

Attach importance to training librarians Yizhuanduoneng. Librarians rotation system implemented library literature information collection, classification, consulting and other work reading has close ties with each other, properly implement rotation system, help librarians understand the whole picture library, establish the overall awareness [7]. Librarian University Library Circulation Department by working in the stacks, carefully understand the needs of readers every day to borrow, borrow traffic statistics all kinds of books, and regularly make reports available to the purchasing department as an adjustment textbook policy basis.

Innovative service concept. If a library of some sort through their own uniqueness: either a certain size and holdings, or an information product, or some special services, the formation of differential advantage in the same industry, then this is the advantage. University Library Service to highlight the features and characteristics of the service. Featured collections, special services, special events, environment and other characteristics can be formed Characteristic Modern College Library Service [7]. University Library Service has its own unique norms and values; the sum of these norms and values is the library culture.

Improve digital library management mode. With the popularity of information networks, many schools have established corresponding digital library, which greatly enriched the literature of library resources, breaking the physical boundaries of the library, the library implements remote services to 
meet the various needs of users. However, the current situation is that electronic preview room Internet Cafe, due to the off-campus Internet cafes charging cheaper than first choice became not computer savvy, so people really need cannot find a seat [8]. Coupled with the system for a long time is not updated so that the digital library cannot be better to play its due role.

Long-term preservation of library resources and Digitizing. Long-term preservation of resources has been the focus of Library and urgent need to resolve the issue. Library resources for saving copies of a two-pronged approach, we strive to extend the life of collections on paper, but also easy to wear and tear will begin collections digitized resources [8]. Strategic planning in the Library of Congress will develop a set of resource conservation measures, including preservation condition monitoring collections, to take measures to extend the life of collections, will turn into other formats consumables, providing basic search function, test new preservation method development and the like. For these measures, the US Library of Congress also plans to expand the research (such as low temperature, proper humidity and illumination, etc.) on collections storage facilities and environmental conditions, and intends to purchase and install environmental monitoring equipment, audio-visual materials to build storage facilities and storage area [8].

\section{Summary}

The emergence of pluralistic access to information, affect library information tissue changes. This requires that the library into the new organizational philosophy of information, user-centric, information resource for effective organization and integration; full use of the Internet to promote the library information resources and Internet integration, expansion of library services space, expand the library user groups, the use of new Internet technologies for information resources deep tissue and display; efficient use of network and user organizations and social forces of the construction of information resource library; full use of interpersonal social networks of information spread, to provide users with multi-channel access to information. The new network environment requires not only the library, as well as coping strategies Library.

\section{References}

[1] J.N.Huang, Books Fundamentals of classification, Chinese Library Journal, 2011, pp.24-28.

[2] Zh.P.Shi, Perceptions of Libraries and Information Resources, Information Research, 2013, pp.34-38.

[3] W.Y. Wang, College and University Library in the Information Age Management, Library Journal, 2012, pp,57-62.

[4] Zh.L. Zhou, he Library of Congress Flickr Pilot Project, Library Studies, 2015, pp.64-68.

[5] Q.Q. Lin, White Paper on the Information Habits of College Students, The Library Journal, 2012, pp.22-26.

[6] S.X. Ding, The integration of digital library resources, Chinese Library Journal, 2014, pp.11-18.

[7] X.X. Li, Internet to the library, Chinese Library Journal, 2014, pp.40-44.

[8] F.Y.Weng and M.Zhang, Macro-organization of the New Century Network Knowledge Information Service, Chinese Library Journal, 2013, pp.33-37. 